\title{
Other Site of New Tumor Event
}

National Cancer Institute

\section{Source}

National Cancer Institute. Other Site of New Tumor Event. NCI Thesaurus. Code C159572.

The site of the new tumor event was identified in the study but is not present in the form. 